\title{
Pengaruh Bauran Pemasaran Jasa Terhadap Kepuasan Anggota Pada Koperasi Syariah (Studi Kasus Pada Bmt Al-Ittihad Pekanbaru)
}

\author{
Arizal. $\mathbf{N}^{1}$, Nofrizal ${ }^{2}$ \\ Dosen Fakultas Ekonomi Universitas Lancang Kuning \\ Jalan Yos Sudarso KM 8 Rumbai \\ Email: arizall_n@yahoo.com \& Email: Nofrizalfe@unilak.ac.id \\ No Hp: 08127533896 dan No Hp: 085225573311
}

\begin{abstract}
The development in the business very rapidly also makes business more challenges in the financial services sector such as Bmt becomes increasingly large, increasingly fierce competition, and the use of increasingly sophisticated technology and consumers are increasingly varied. This condition is indirectly demanded Bmt to be able to further develop better strategies in marketing, production, employee, as well as in the financial sector so as to meets what the wants and needs of each of its customers as well as increase the number of members or customers. Like at Bmt Al Ittihad, which is one of the many cooperatives that have sharia potential to grow in pekanbaru, because Bmt Al Ittihad increased member / new customer every year. This research directed to address problems if the marketing mix consisting of product, prices, promotion, people, process, location and physical evidence and service quality then influence the satisfaction of members of Bmt Al Ittihad and the benefits of this research is expected to provide evaluation of policies and marketing strategies must be taken related to what the needs and tastes of members of Bmt Al Ittihad. These results indicate all variable have to influence simultaneous marketing mix consisting of product, promotion, process, price, employees, places, physical evidence and service quality. And then as test parsial results only physical evidence and place have to influence of satisfaction member of Bmt Al Ittihad.
\end{abstract}

Keywords: Members Satisfaction, Marketing Mix Service and Service quality

Seiring dengan munculnya era globalisasi, perkembangan dalam dunia bisnis saat ini mengalami pertumbuhaan yang begitu pesat, baik bisnis yang bergerak di bidang manufatur (produk) maupun di bidang jasa. Pada sektor jasa, dinamika ini dapat terlihat dari semakin berkembangnya berbagai bentuk lembaga keuangan syariah seperti bank syariah, pengadian syariah, asuransai syariah serta kelembagaan keuangan syariah seperti Baitul Mal wa Tamwil (BMT). Adanya perkembangan dalam dunia bisnis yang sangat pesat juga menjadikan tantangan dalam bisnis sektor jasa keuangan seperti BMT menjadi semakin besar, persaingan yang semakin ketat, dan penggunaan teknologi yang semakin canggih, serta konsumen yang semakin variatif. Kondisi ini secara tidak langsung menuntut BMT untuk dapat semakin mengembangkan strategi baik bidang marketing, produksi, personalia, maupun di bidang keuangan sehingga dapat memenuhi apa yang menjadi keinginan dan kebutuhan dari setiap nasabahnya.

Memelihara dan membuat nasabah BMT Al-Ittihad merasa puas sehingga menimbulkan loyalitas dengan jasa yang diberiakan pada era bisnis masa kini merupakan tuntutan yang harus segera dilaksanakan, karena dengan dipeliharanya loyalitas dan membuat nasabah merasa puas maka keberadaan BMT dapat terjaga. Nasabah yang loyal dan merasa puas dengan jasa / pelayaan yang diberikan oleh BMT ini akan memanfaatkan ulang jasa BMT dan juga melakukan kegiatan word of mouth melalui pemberian rekomendasi kepada orang-orang terdekat. Untuk mencapai kepuasan nasabah/ anggota, BMT harus bisa menentukan strategi pemasaran yang tepat agar usahanya dapat bertahan dan tujuan utamanya dapat tercapai. Karena itu BMT perlu menerapkan strategi pemasaran yang baik. Salah satu strategi pemasaran yang banyak dipakai adalah 
bauran pemasaran (Marketing Mix). Bauran pemasaran jasa terdiri dari product (produk), Price (harga), place (lokasi), Promotion (promosi), people or participant (penyedia jasa/orang), process (proses jasa), dan physical evidence (bukti fisik).

Menurut Kotler dan Amstrong (2008) Pemasaran mengandung arti bahwa proses dimana perusahaan menciptakan nilai bagi pelanggan dan membangun hubungan yang kuat dengan pelanggan dengan tujuan untuk menangkap nilai dari dari pelanggan sebagai imbalannya dalam buku pemasaran jasa. Sedangkan menurut Kotler dan Kevin (2009) mendefinisikan bahwa jasa adalah suatu aktivitas ekonomi yang ditawarkan satu pihak kepada pihak lain. Sering kali kegiatan yang dilakukan dalam jangka waktu tertentu (time-base), dalam suatu kegiatan (perfomances) yang akan membawa hasil yang diinginkan penerima, objek, maupun aset-aset lainnya yang menjadi tanggu jawab dari pembeli. Sebagai pertukaran dari uang, waktu, dan upaya, pelanggan jasa akan berharap nilai (value) dari suatu akses dari barang-barang, tenaga kerja, tenaga ahli, fasilitas, dan sistem tertentu,tetapi para pelanggan biasanya tidak akan mendapatkan hak milik dari unsur-unsur fisik yang terlibat dalam penyediaan jasa tersebut.

Para pemasaran menggunakan alat untuk mendapatkan tanggapan yang diinginkan dari pasar sasaran mereka, alat itu membentuk suatu bauran pemasaran (marketing mix). Menurut Ratih Hurriyati (2008) pengertian bauran pemasaran jasa adalah sebagai berikut: "Bauran pemasaran jasa adalah elemen-elemen organisasi perusahaan yang dapat dikontrol oleh perusahaan dalam melakukan komunikasi dengan konsumen dan akan dipakai untuk memuaskan konsumen." Fandy Tjiptono (2007) mendefinisikan bauran pemasaran sebagai berikut: "Bauran pemasaran (marketing mix) adalah seperangkat alat pemasaran yang digunakan perusahaan untuk terus-menerus mencapai tujuan pemasarannya di pasar sasaran. Menurut Fandy Tjiptono (2007:18) bauran pemasaran jasa adalah terdiri dari 7P's, yaitu: product (produk), price (harga), place (lokasi), promotion (promosi), people or participant (penyedia jasa/orang), process (proses jasa), dan physical evidence (bukti fisik).

Penelitian Terdahulu

Penelitian ini dilakukan tidak terlepas dari hasil penelitian-penelitian terdahulu yang pernah dilakukan sebelumnya untuk bahan perbandingan dan kajian. Adapun hasil-hasil penelitian yang dihasilkan perbandingan tidak terlepas dari topik penelitian yaitu mengenai Pengaruh bauran pemasaran terhadap tingkat kepuasan pelanggan warung sate kelinci di kota batu yang dilakukan oleh Narisah, Bambang Ali Nugroho dan Budi Hartono (2014) hasil penelitian yang mereka lakukan menunjukan hasil bahwa Kepuasan pelanggan sate kelinci di warung Jalan Patimura 126 paling dipengaruhi oleh "produk dan pelayanan", dan "tempat dan harga", sedangkan kepuasan pelanggan sate kelinci di warung Jalan Suropati paling dipengaruhi oleh "tempat berjualan", "pelayanan warung", dan "harga terjangkau dan diskon".

Penelitian yang dilakukan oleh Berlian Aminanti Suraya Putri (2012) yang berjudul Pengaruh bauran pemasaran terhadap kepuasan pelanggan (studi kasus di toko dannis collection pati). Hasil penelitianya menunjukan bahwa Variabel bauran pemasaran $(\mathrm{X})$ mempunyai peran yang signifikan terhadap kepuasan pelanggan di toko busana muslim DANNIS Collection Pati. Terlihat $\mathrm{t}$ hitung $(0,460)>\mathrm{t}$ tabel (1,6736) yang berarti bauran pemasaran mempunyai andil dalam mempengaruhi kepuasan pelanggan pada toko busana muslim DANNIS Collection Pati. Terlihat $\mathrm{F}$ hitung sebesar 6,212 dengan nilai signifikansi 0,047 , karena nilai signifikan lebih kecil dari 0, 05, yang bauran pemasaran mempunyai andil dalam mempengaruhi kepuasan pelanggan pada toko busana muslim DANNIS Collection Pati. Diantara produk, harga, lokasi, dan

p.ISSN: 2407-800X e.ISSN: 2541-4356 
194 Pengaruh Bauran Pemasaran Jasa Terhadap Kepuasan Anggota Pada Koperasi Syariah (Studi Kasus Pada Bmt Al-Ittihad Pekanbaru) (Arizal dan Nofrizal)

promosi yang paling berpengaruh terhadap kepuasan pelanggan adalah bagian produk.

\section{METODE}

Jenis penelitian yang digunakan oleh peneliti adalah penelitian Kuantitatif yang bertujuan untuk menganalisis hubungan-hubungan antara satu variabel dengan variabel lainnya atau bagaimana suatu variabel mempengaruhi variabel lainnya dan sifat penelitian ini adalah survei. Lokasi

Penelitian ini dilakukan pada BMT Al-Ittihad Rumbai yang beralamat di Komplek Damar CPI Pekanbaru. Metode Pengumpulan Data: Observasi dan kuesioner. Dalam penelitian ini populasi yang dimaksud adalah seluruh Anggota BMT Al-Ittihat pada tahun 2014 yang berjumlah 400 orang. Jumlah populasi yang besar maka perlu diambil sampel. Ukuran sampel pada penelitian ini menggunakan pendapat slovin dengan tingkat error 10 persen, dan jumlah sampel adalah dari perhitungan, maka dapat diketahui bahwa jumlah sampel yang digunakan dalam penelitian ini sebanyak 80 orang. Teknik pengambilan sampling yang digunakan adalah non probability sampling.

\section{HASIL}

Dari pengujian diperoleh hasil pengamatan dan mengelolahan data ditemukan bahwa bahwa produk, promosi, proses, harga, karyawan, tempat dan bukti fisik berpengaruh secara simultan terhadap kepuasan anggota BMT Al-Ittihad. Hal tersebut dapat dilihat dari hasil uji $\mathrm{F}$ yang mendapatkan hasil signifikansi sebasar 0.000 $<0,05$. Sedangkan secara parsial variable tempat dan bukti fisik berpengaruh positif dan signifikan terhadap kepuasan anggota dengan harga thitung 3.514> tabel 1,990 dimana nilai signifikannya adalah $0.001<\alpha$ 0,05. Hal ini disebabkan lokasi BMT AlIttihad yang mudah di jangkau oleh anggota dengan barbagai alat transfortasi umum.

Sedangkan variable bukti fisik Harga ${ }^{t}$ hitung 3.403> ${ }^{t}$ tabel 1,990 dimana nilai signifikannya adalah $0.001<\alpha \quad 0,05$ yang berarti variable bukti fisik berpengaruh positif dan signifikan terhadap kepuasan anggota. Hal ini disebabkan BMT AlIttihad memiliki interior dan eksterior yang sudah mendekati sistem yang digunakan oleh Bank Umum dengan menggunakan standar -standar yang dimiliki oleh Bank umum dan diterapkan di BMT Al-Ittihad maka tingkat kepuasaan anggotapun mengalami peningkatan. Dengan hasil sebagaimana yang telah diuraikan tersebut diatas, maka hipotesisis penelitian dapat diterima kebenaranya. Diterimanya hipotesisi ini sejalan pula dengan landasan teori Menurut Fandy Tjiptono (2007:18) bauran pemasaran jasa adalah terdiri dari 7P's, yaitu: product (produk), price (harga), place (lokasi), promotion (promosi), people or participant (penyedia jasa/orang), process (proses jasa), dan physical evidence (bukti fisik) memiliki pengaruh positif jika kualitasnya di tingkatkan terhadapa terwujudnya kepuasaan.

Kesimpulan ini juga sekaligus mendukung penelitian sebelumnya yang menemukan adanya keterkaitan atau pengaruh yang positif dan signifikan antara produk, promosi, proses, harga, karyawan , temapat dan bukti fisik terhadap kepuasaan (Fitriani Dayasari Hasan, 2012). Dan juga mendukung penelitian yang dilakukan oleh Penelitian Soraya (2009) berjudul "Pengaruh Bauran Pemasaran Jasa terhadap Keputusan Pembelian Konsumen pada Gardenia Cafe Medan". Penelitian ini menggunakan jenis penelitian asosiatif kausal, yang terdiri dari Produk (X1), Harga (X2), Tempat (X3), Promosi (X4), Orang (X5), Bukti Fisik (X6) dan Proses (X7) serta Keputusan Pembelian (Y). Hasil penelitian menunjukkan bahwa variabel Produk (X1), Harga (X2), Tempat (X3), Promosi (X4), Orang (X5), Bukti Fisik (X6) dan Proses (X7) secara bersama-sama berpengaruh positif dan signifikan terhadap Keputusan Pembelian Konsumen (Y).

p.ISSN: $2407-800 X \quad$ e.ISSN: $2541-4356$ 


\section{PEMBAHASAN}

Umur responden anggota BMT-ALIttihad Rumbai yang diambil sebagai responden, menunjukan bahwa mayoritas umur responden adalah 46-50 tahun dengan $62.5 \%$

Jenis Kelamin. Jenis kelamin responden anggota BMT-AL-Ittihad Rumbai yang diambil sebagai responden, menunjukan bahwa mayoritas jenis kelamin responden adalah laki-laki yaitu $78 \%$.

Pendidikan. Mayoritas tingkat pendidikan responden adalah Strata satu (S1) dengan $73.8 \%$. Hal ini menunjukan bahwa sebagian besar dari responden anggota BMT ALIttihad memiliki tingkat pengetahuan yang cukup bagus. Menunjukan bahwa mayoritas status perkawinan responden adalah menikah dengan tingkat $95.0 \%$. Hal ini menunjukan bahwa sebagian besar dari responden anggota BMT AL- Ittihad sudah menikah dan memiliki tanggung jawab terhadap kelurganya. Mayoritas lama kenaggotan adalah 9 tahun keatas dengan nilai $36.3 \%$. Hal ini menunjukan bahwa sebagian besar anggota BMT AL- Ittihad memiliki tingkat keloyalan menjadi anggota yang tinggi

Dari ke -19 peryataan yang diukur lihat Tabel dibawah ini, hanya dua peryataan yang dinilai cukup yakni BMT AL- Ittihad menawarkan produk beragam dan Karyawan BMT AL-ITTIHAD memberikan sunguhan berupa permen/air mineral dalam melayani nasabah. Penilian ini berdasarkan produkproduk yang ditawarkan oleh BMT Al-Ittihad yang masih terbatas dan tidak beragam sedangkan untuk anggota menawarkan air mineral ke anggota dinilai berdasarkan hasil kuisiner dan memang pihak BMT Al-Ittihad tidak memberikan air mineral kepada anggota yang datang ke BMT Al-Ittihad.

Tabel. Rekapitulasi

Tanggapan

\section{Responden}

Pemasaran jasa

\begin{tabular}{|c|c|c|c|c|c|c|c|c|c|}
\hline \multirow{2}{*}{$\begin{array}{l}\mathbf{N} \\
\mathbf{O}\end{array}$} & VARIA & $\begin{array}{l}\mathbf{S} \\
\mathbf{S}\end{array}$ & $\mathbf{S}$ & $\begin{array}{l}\mathbf{C} \\
\mathbf{S}\end{array}$ & $\begin{array}{l}\mathbf{T} \\
\mathbf{S}\end{array}$ & $\begin{array}{r}\text { K } \\
\text { TS }\end{array}$ & \multirow{2}{*}{$\begin{array}{r}\text { Tot } \\
\text { al }\end{array}$} & \multirow{2}{*}{$\begin{array}{r}\text { Sk } \\
\text { or } \\
\text { rat } \\
\text { a- } \\
\text { rat } \\
\mathbf{a} \\
\end{array}$} & \multirow{2}{*}{$\begin{array}{c}\text { Krite } \\
\text { ria } \\
\text { Pelay } \\
\text { an }\end{array}$} \\
\hline & BLE & 5 & 4 & 3 & 2 & 1 & & & \\
\hline & $\begin{array}{l}\text { PRODU } \\
\mathrm{K}\end{array}$ & & & & & & & & \\
\hline
\end{tabular}

Jurnal Daya Saing

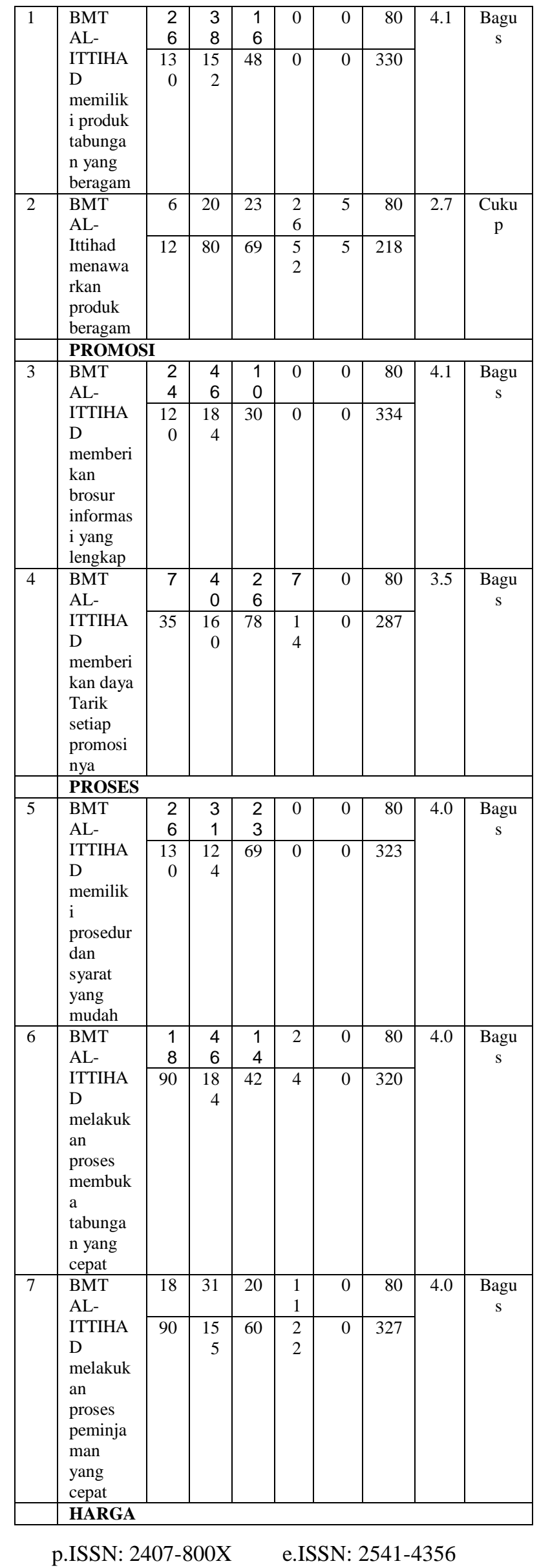


196 Pengaruh Bauran Pemasaran Jasa Terhadap Kepuasan Anggota Pada Koperasi Syariah (Studi Kasus Pada Bmt Al-Ittihad Pekanbaru) (Arizal dan Nofrizal)

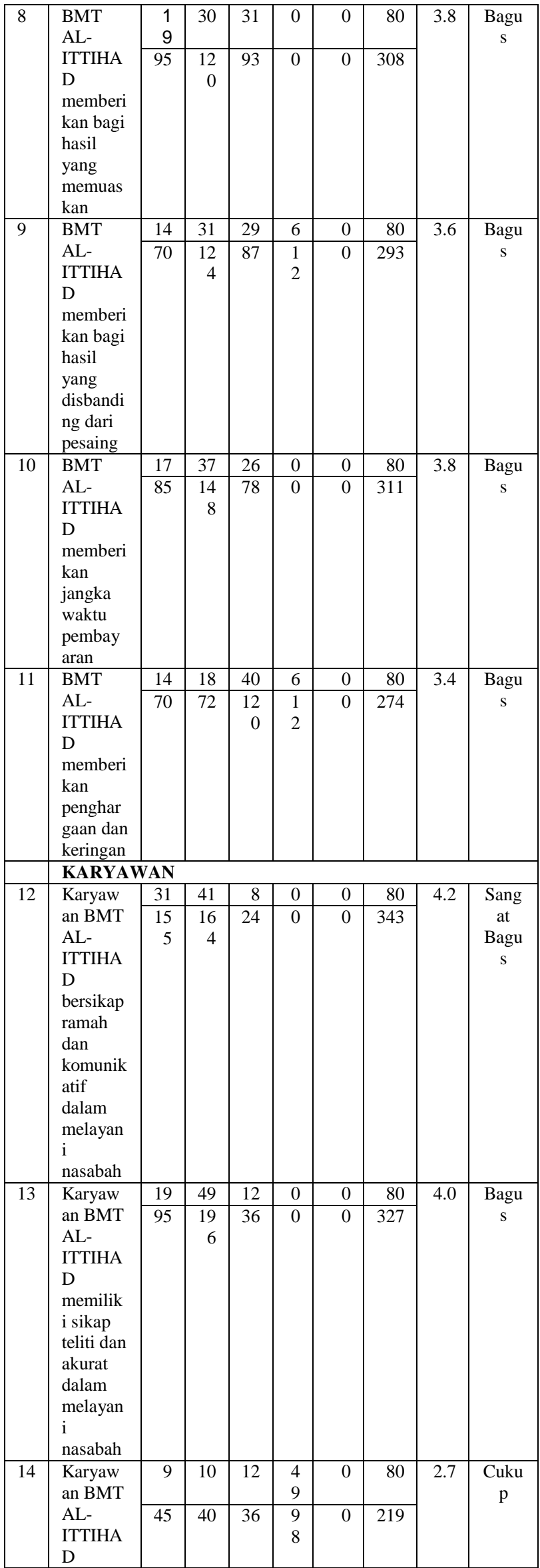

Jurnal Daya Saing

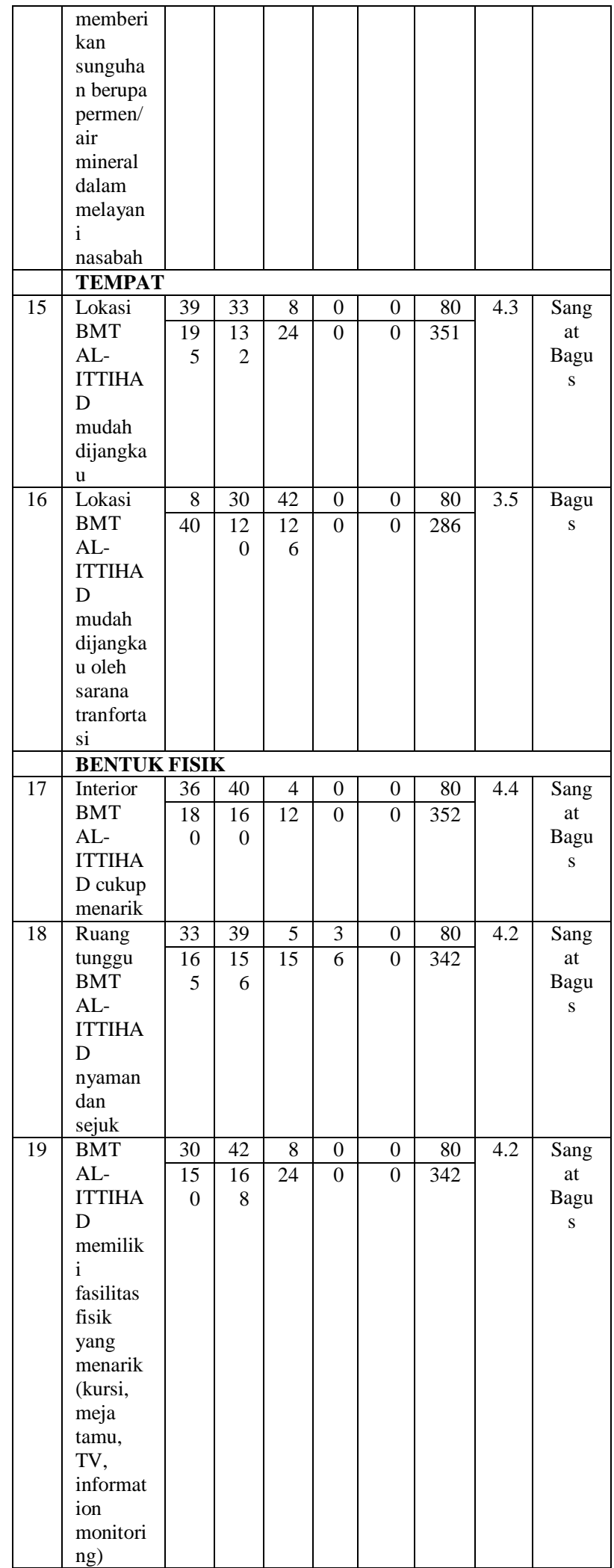

Hasil penelitan pada table 2 menyimpulkan bahwa secara umum para anggota di BMT Al-Ittihad merasa puas . hasil ini sejalan dengan temuan 
sebelumnya yang menunjukan bahwa hasil penelitian yang bagus terhadap BMT AlIttihad

Tabel 2. Rekapitulasi Responden Pada Tanggapan Kepuasaan

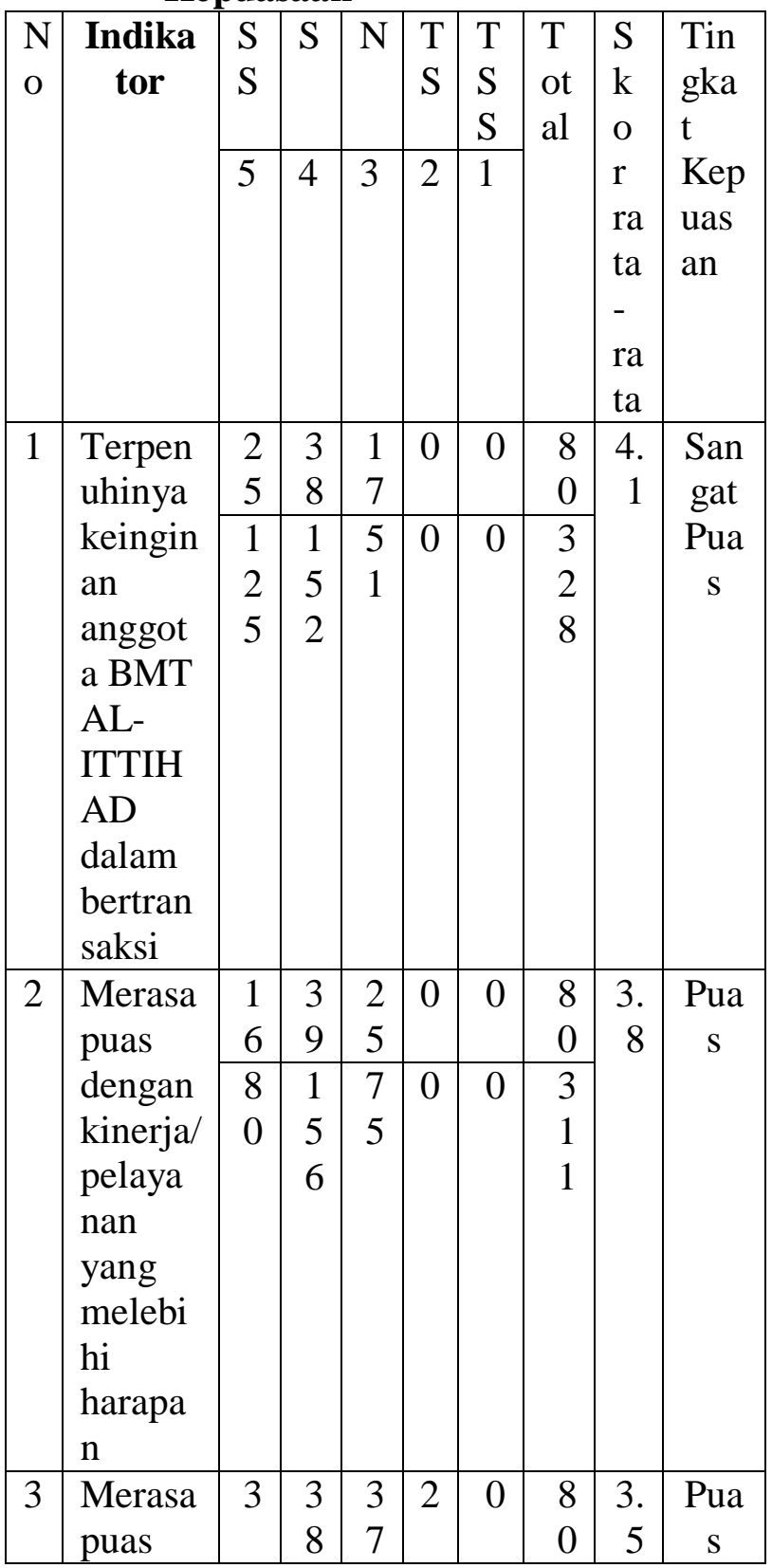

Jurnal Daya Saing

\begin{tabular}{|l|l|l|l|l|l|l|l|l|}
\hline dengan & 1 & 1 & 1 & 4 & 0 & 2 & & \\
produk & 5 & 5 & 1 & & & 8 & & \\
- & & 2 & 1 & & & 2 & & \\
produk & & & & & & & & \\
BMT & & & & & & & & \\
AL- & & & & & & & & \\
ITTIH & & & & & & & & \\
AD & & & & & & & & \\
\hline
\end{tabular}

Data sekunder dengan model time series perlu digunakan uji linieritas. Uji linearitas adalah pengujian yang bertujuan untuk mengetahui apakah regresi bersifat linier atau tidak. Uji linieritas dalam penelitian ini menggunakan tabel ANOVA variabel $\mathrm{X}$ dan $\mathrm{Y}$ dari nilai signifikan. Apabila nilai signifikan tabel ANOVA < 0,05 maka dapat disimpulkan bahwa hubungan bersifat linier. Uji linier dalam penelitian ini juga menggunakan spss dengan hasil pengujian sebgai berikut:

Tabel 4. Uji Linier ANOVA $^{\mathrm{a}}$

\begin{tabular}{|c|c|c|c|c|c|}
\hline Model & $\begin{array}{c}\text { Sum of } \\
\text { Square } \\
\text { s }\end{array}$ & Df & $\begin{array}{c}\text { Mean } \\
\text { Squar } \\
\text { e }\end{array}$ & $\mathrm{F}$ & Sig. \\
\hline $\begin{array}{ll}1 & \text { Regressio } \\
\mathrm{n}\end{array}$ & 8.827 & 7 & 1.261 & $\begin{array}{r}12.56 \\
0\end{array}$ & .000 \\
\hline Residual & 7.229 & $\begin{array}{l}7 \\
2\end{array}$ & .100 & & \\
\hline Total & 16.055 & $\begin{array}{l}7 \\
9\end{array}$ & & & \\
\hline
\end{tabular}

a. Dependent Variable: $Y$

b. Predictors: (Constant), X7, X1, X3, X2, X6, X5, $\mathrm{X} 4$

Hasil Pengujian Hipotesis

Hasil pengujian regresi linier berganda menghasilkan informasi sebagai berikut:

Tabel 5. Hasil Analisis Regersi Berganda

\begin{tabular}{|c|r|r|}
\hline Komponen Regresi & Konstanta & Harga ${ }^{\text {thitung }}$ \\
\hline Koefisien regresi & -0.298 & \\
\hline X1 Produk & & 2.191 \\
\hline X2 Promosi & & -0.698 \\
\hline X3 Proses & & 0.981 \\
\hline X4 Harga & & 2.602 \\
\hline X5 Karyawan & & 2.841 \\
\hline X6 Tempat & & 3.514 \\
\hline X7 Bukti fisik & & 3.403 \\
\hline
\end{tabular}

Sumber : Data olahan 2016.

p.ISSN: $2407-800 X$

e.ISSN: $2541-4356$ 
Tabel tersebut memberikan beberapa analisis yang bisa dicermati, mencakup pada permasaaan regresi, pengujian signifikan simultan, koefisien determinasi dan korelasi. Baris koefisien regrasi pada tabel di atas dapat dijadikan dasar bagi penyusunan sebuah persamaan regresi : $\mathrm{Y}=-0.298+$ $2.191+-0.698+0.981+2.602+2.841+3.514+$ $3.403+$ ei, dimana persamaan ini dimaknai sebagai berikut: Jika diasumsikan variable produk adalah konstan atau sama dengan nol, maka tingkat kepuasan anggota BMT AlIttihad akan bernilai sebesar -0.298 . nilai ini berasal dari kondisi kepuasan anggota yang telah ada selama ini tanpa andanya suatu upaya peningkatan yang dilakukan pihak BMT Al-Ittihad, atau berasal dari kontribusi variable-variable lainya. Jika diasumsikan variable produk terjadi peningkatan sebesar satu satuan, maka akan terjadi peningkatan pada kepuasan anggota BMT Al-Ittihad sebesar 0,2.191 . Artinya, semakin baik kualitas produk yang anggota rasakan akan semakin memperbesar tingkat kepuasan anggota.

\section{Uji Simultan (Uji-F)}

\begin{tabular}{|c|c|c|c|c|c|}
\hline \multicolumn{6}{|c|}{ ANOVA $^{a}$} \\
\hline Model & $\begin{array}{c}\text { Sum of } \\
\text { Square } \\
s\end{array}$ & Df & $\begin{array}{l}\text { Mean } \\
\text { Squar } \\
\text { e }\end{array}$ & $\mathrm{F}$ & Sig. \\
\hline $\begin{array}{ll}1 \text { Regressio } \\
n\end{array}$ & 7.878 & 7 & 1.125 & $\begin{array}{r}11.06 \\
5\end{array}$ & .000 \\
\hline Residual & 7.324 & $\begin{array}{l}7 \\
2\end{array}$ & .102 & & \\
\hline Total & 15.202 & $\begin{array}{l}7 \\
9\end{array}$ & & & \\
\hline
\end{tabular}

a. Dependent Variable: $Y$

b. Predictors: (Constant), X7, X1, X5, X3, X6, X2, X4

Dari pengujian tabel diatas, diperoleh hasil pengamatan bahwa produk, promosi, proses, harga, karyawan, tempat dan bukti fisik berpengaruh secara simultan terhadap kepuasan anggota BMT Al-Ittihad. Hal tersebut dapat dilihat dari hasil uji $\mathrm{F}$ yang mendapatkan hasil signifikansi sebasar 0.000 $<0,05$. Uji Parsial (Uji-t)

Pengujian ini dimaksudkan untuk mengetahui besar pengaruh variable produk, promosi, proses, harga, karyawan, tempat Jurnal Daya Saing dan bukti fisik terhadap kepuasan anggota. Dikatan berpengaruh signifikan jika nilai $\mathrm{t}_{\text {hitung }}>^{\mathrm{t}}$ tabel dengan tingkat kepercayaan $5 \%$ atau $\alpha=0,05$ nilai tabel $=\alpha: \mathrm{dk}=\mathrm{n}-2$ dimana $\alpha=0,1$ dan $n=80$ berdasarkan tabel t maka nilai tabel adalah sebesar 1,990.

\section{PEMBAHASAN}

Berdasarkan tabel di atas dapat diambil kesimpulan sebagai berikut: Harga thitung $2.191<{ }^{\mathrm{t}}$ tabel 1,990 dimana nilai signifikannya adalah $0.543>\alpha \quad 0,05$ yang berarti variable produk berpengaruh dan signifikan terhadap kepuasan anggota $\mathrm{H} 1$ (ditolak). Harga ${ }^{t}$ hitung $-0.698<{ }^{t}$ tabel 1,990 dimana nilai signifikannya adalah $0.032>\alpha$ 0,05 yang berarti variable promosi tidak berpengaruh signifikan terhadap kepuasan anggota H2 (ditolak). Harga ${ }^{\mathrm{t}}$ hitung 0.981< tabel 1,990 dimana nilai signifikannya adalah $0.330>\alpha 0,05$ yang berarti variable proses tidak berpengaruh signifikan terhadap kepuasan anggota H3 (ditolak). Harga thitung $2.602>$ tabel 1,990 dimana nilai signifikannya adalah $0.011>\alpha 0,05$ yang berarti variable harga tidak berpengaruh signifikan terhadap kepuasan anggota H4 (ditolah. Harga ${ }^{t}$ hitung 2.841> tabel 1,990 dimana nilai signifikannya adalah $0.006<\alpha 0,05$ yang berarti variable karyawan tidak berpengaruh signifikan terhadap kepuasan anggota $\mathrm{H} 4$ (ditolak). Harga thitung 3.514> tabel 1,990 dimana nilai signifikannya adalah $0.001<\alpha \quad 0,05$ yang berarti variable tempat berpengaruh positif dan signifikan terhadap kepuasan anggota H5 (diterima). Harga thitung 3.403> tabel 1,990 dimana nilai signifikannya adalah $0.001<\alpha 0,05$ yang berarti variable bukti fisik berpengaruh positif dan signifikan terhadap kepuasan anggota H6 (diterima).

Adapun nilai koefisien korelasi (R) sebesar 0.741 , menunjukan bahwa terdapat hubungan yang kuat anatara variable produk, promosi, proses, harga, karyawan, tempat, dan bukti fisik dengan tingkat kepuasan anggota BMT Al-Ittihad. Implikasinya, setiap ada peningkatan p.ISSN: $2407-800 X \quad$ e.ISSN: 2541-4356 
variable produk, promosi, proses, harga, karyawan, tempat, dan bukti fisik, maka tingkat kepuasan anggota BMT Al-Ittihad akan meningkat. Dan demikian pula sebaliknya

\section{SIMPULAN}

Penelitian ini bertujuan untuk mengetahui variabel apa saja yang mempengaruhi kepuasan anggota BMT AlIttihad. Sesuai dengan hasil dan analisis yang dikemukakan pada pembahasan sebelumnya, maka dapat ditarik kesimpulan sebagai berikut : Bahwa produk, promosi, proses, harga, karyawan, tempat dan bukti fisik berpengaruh secara simultan terhadap kepuasan anggota BMT Al-Ittihad. Produk tidak berpengaruh terhadap kepuasaan anggota BMT Al-Ittihad. Hal ini menunjukkan bahwa produk tidak mempengaruhi kepuasana anggota BMT Al-Ittihad. Promosi tidak berepengaruh terhadap kepuasaan anggota BMT Al-Ittihad. Hal ini menunjukkan bahwa Promosi tidak mempengaruhi kepuasaan anggota BMT Al-Ittihad. Proses tidak berpengaruh terhadap kepuasaan anggota BMT Al-Ittihad. Hal ini menunjukkan bahwa proses tidak mempengaruhi kepuasaan anggota BMT Al-Ittihad.

Harga tidak berpengaruh terhadap kepuasana anggota BMT Al-Ittihad. Hal ini menunjukkan bahwa harga tidak mempengaruhi kualitas kepuasaan anggota BMT Al-Ittihad. Karyawan tidak berpengaruh terhadap kepuasana anggota BMT Al-Ittihad. Hal ini menunjukkan bahwa karyawan tidak mempengaruhi kualitas kepuasaan anggota BMT Al-Ittiha. Tempat berpengaruh positif dan signifikan terhadap kepuasan anggota BMT Al-Ittihad. Hal ini menunjukkan bahwa semakin mudah dijangkau, maka akan semakin baik kepuasaan anggota BMT AlIttihad. Bukti fisik berpengaruh positif dan signifikan terhadap kepuasan anggota BMT Al-Ittihad. Hal ini menunjukkan bahwa semakin tinggi kualitas bukti fisik, maka akan semakin baik kepuasaan anggota BMT Al-Ittihad.

\section{DAFTAR RUJUKAN}

Kotler, Philip dan Gary Armstrong. 2008, Prinsip-Prinsip Pemasaran. Edisi ke-12. Erlangga. Jakarta.

Kotler Philip dan Kevin L. Keller. 2009, Manajemen Pemasaran. Edisi ke13. Penerbit Erlangga. Jakarta.

Ratih Hurriyati,. 2008, Bauran Pemasaran dan Loyalitas Konsumen. Alfabeta. Bandung

Fandy Tjiptono,. 2008, Strategi Pemasaran. Edisi 5. Penerbit Andi. Yogyakarta

Narisah, Bambang Ali Nugroho dan Budi Hartono, 2014, Pengaruh Bauran Pemasaran Terhadap Tingkat Kepuasan Pelanggan Warung Sate Kelinci Di Kota Batu, Jurnal AKK, Volume 1, No.1, Hal:1-55

Berlian Aminanti Suraya Putri, 2012, Pengaruh Bauran Pemasaran Terhadap Kepuasan Pelanggan (Studi Kasus Di Toko Dannis Collection Pati), Skripsi, Fakultas Ekonomi, Universitas Brawijaya, Malang 